The effects of this change of physical feature must obviously have been manifold. The existence of a great Central Asiatic Sea would greatly temper the Siberian climate, while the southern flow of its rivers would affect the distribution of animal and vegetable life, and offers at least a reasonable solution of the difficulties surrounding the migration of birds in the Palæarctic region, while it finally sweeps away the hypothesis that the Mammoth remains of Siberia are the wreckage of river portage.

III.-Note on the Classification of the Red Rocks in SouthEast Durham; and on a possible unconformity between the Trias and the Permian Limestone in the same District.

By H. H. Howetu, F.G.S., ete.,

Director of the Geological Survey of Scotland.

THE several bore-holes which have been put down through the 1 Red Rocks in the south-east part of the county Durham to win the bed of Rock Salt there have directed attention to the age and classification of these rocks.

Mr. Edward Wilson in an exhaustive paper published in the Quarterly Journal of the Geological Society of London, has strongly supported the classification adopted and expressed on the maps of the Government Geological Survey of that district.

Mr. Howse, in the "Guide to the Collections of Local Fossils in the Museum of the Natural History Society, Newcastle-on-Tyne," recently issued, classes the whole of the Red Rocks down to and including the Salt-bed as Trias, but does not divide them into Upper and Lower divisions. He says, "It seems better to conclude that the red shales and sandstones at the mouth of the Tees represent a peculiar and local development of the Trias than attempt to split it up into divisions that have no exact representatives either in England or on the Continent."

Professor Lebour, formerly on the staff of the Geological Surrey in Northumberland, in the "Handbook to the Geology and Natural History of Northumberland and Durham," which appears to be in part a re-issue (in the form of an "Official and Local Guide" prepared by him for the meeting of the British Association at Newcastle in 1889), of the second edition of his "Outlines of the Geology of Northumberland and Durham," published in 1886, gives his most recent riews on the classification of the rocks between the Permian Magnesian Limestone and the Drift. He gives the following scheme merely as representing his own opinions derived from a careful examination of the evidence at present available on the subject :-

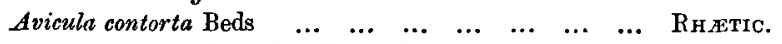

(Proved in Eston shaft and boring.)

7. $\{$ Red and Green Marls with Gypsum (known only south ) UPPER

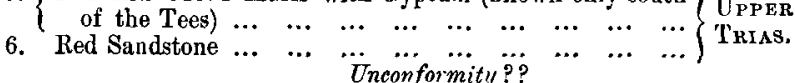

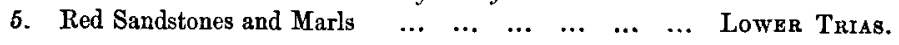




\section{Unconformity? ?}

4. Red Marly Sandstones, Marls, with lenticular beds of ) UPPER Anhydrite, Gypsum, and Salt, and foetid limestone in Permiar variable bands towards the base ...

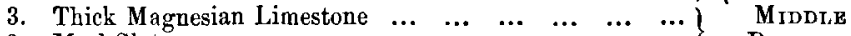

2. Marl Slate ...

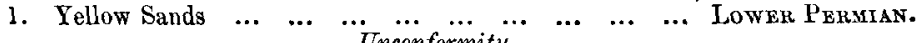
Unconformity.

And further on, at p. 31, Professor Lebour criticizes the scheme adopted by the Geological Survey. I give the extract in full. $\mathrm{He}_{\theta}$ says, "When I first entered upon the study of this question, I was strongly prejudiced in favour of the view of the stratigraphical relations of these beds which is represented by the scheme according to which the maps of the Geological Survey are coloured, viz. :-

\section{RH AtTIC.}

Upper Trias
(Keuper).
Permiax. - Magnesian Limestone.

But there seems to be no good reason, in the total absence of fossils, for separating what I have called No. 4, into two divisions, the lower with and the upper without limestones. It is true that the reason for separating No. 5 from No. 4 is scarcely stronger, except that there is a distinct evidence that the former division now occupies a larger area than the latter, which is proof of overlap, if not of unconformity. There is also some, though less, evidence of No. 6 overlapping No. 5, or being unconformable to it, and there seems to be absolutely nothing in favour of the assumption that (whichever classification be adopted) the Triassic Series is in South Durham only represented by the Keuper."

As I was District Surveyor in charge of the Geological Survey of that district, and to some extent responsible for the classification adopted and expressed in the maps of the Geological Survey, I may be permitted to explain the reasons which induced me to recommend that the whole of the red rocks lying between the Rhætics and the Durham Permian Limestone should be classed as Trias, and as belonging to the Upper or Keuper division of that formation.

Now the position of the Rhretic beds on the Yorkshire side of the Tees is well known, and beneath them there is something like from 400 to 500 feet of Red Marls-the Keuper Marls-which graduate down into Sandstones with beds of Red Marl-the Lower Keuper Sandstones or Waterstones-of other districts in Britain. Down to this horizon I believe all are agreed-there is no difference of opinion-that these strata belong to the Keuper division of the Trias.

But in this district beneath these undoubted Keuper beds, there is a great-an abnormal thickness of sandstones, sandy marls, and marly sandstones, with thick deposits of gypsum and anhydrite at their base, with which the bed of Rock Salt is associated, which cannot be very well correlated with other districts.

When I was engaged on the Geological Survey there, the difficulty presented itself to me as to what these red rocks should 
be called, and it was not neglected. Any one who will look at the Drift editions of the Geological Survey maps will see at a glance that the whole of the low-lying district bordering on the Tees in S.E. Durham and North Yorkshire is covered by an almost unbroken sheet of Glacial Drift and alluvial deposits which mask the underlying solid rocks; therefore sections of the red rocks exposed at the surface are few and far between. They are visible at Seaton Carew, and up the Tees at Coatham Stob, Dinsdale, Hurworth, and Croft. I examined all these sections, and it was my opinion then and it is my opinion now that the rocks have a distinctly Keuper aspect. They are not in the least like the Bunter-the soft upper and lower brick red sandstones with intervening pebble beds, which I mapped in my younger days in the Midland Connties, and which I was taught to regard as Bunter. I have also examined the cores of these rocks brought up at several bore-holes, and they tend to confirm me in this opinion. Neither could I find any trace of a physical break or unconformity within these red rocks-they seemed to be due to one continuous deposition. In the face of this evidence it does seem to me that it would have been absurd to split up the red rocks into divisions and draw hypothetical lines separating Keuper Sandstones and Marls from Bunter Sandstones and Marls, and Bunter Sandstones and Marls from Permian marly Sandstones and Marls. Therefore, I felt compelled to carry the base-line down to an horizon where the lithological characters were marked and distinct, viz. to the junction of the red rocks with the Durbam Permian Limestone. And there is also at this horizon, I think, some evidence of a possible unconformity. I use the word "possible" advisedly, because I am not very sure that the position of the Triassic rock on the Permian Limestone may not be explained in another way. But the evidence for the unconformity, such as it is, is this. At the Seaton Carew bore-hole, I think it has been undoubtedly proved that the red rocks with gypsum and anhydrite at their base rest upon the upper division of the Durham Permian Limestone-that division which comes to the surface in the cliffs at Hartlepool and at other places along the Durbam coast. The stratigraphical position of this division is from 700 to 800 feet above the Marl Slate. Then again in the flat country bordering upon the estuary of the Tees numerous bore-holes have been put down through the red rocks to work the salt-bed there, and some of these borings have been carried down into limestones beneath the salt-bed. It has been stated more than once that these limestones were not fossiliferous, and could not be identified with any beds coming to the surface at the outcrop. As regards one bore-hole this is most certainly a mistake. I refer to the one which was put down for the Newcastle Chemical Company on reclaimed land on the north side of the Tees opposite Middlesborough. I was consulted about this boring from the first, therefore I am well acquainted with it. The section of the red rocks passed through agreed very closely with that of neighbouring bore-holes, with the exception of the absence 
of the salt-bed, which was unfortunate commercially, but does not materially affect the question under discussion.

I recollect very well when resident at Darlington, Mr. Wilton Allbusen bringing me a portion of the first core of limestone which had been bored through, and asking my opinion whether the horizon of the salt-bed had been passed, and whether there was any prospect of success by continuing the bore-hole deeper into the limestone.

I told him the fact of reaching the limestone after passing through the red rocks without finding the salt-bed proved the latter to be absent, and that there would be no prospect of success by going deeper into the limestone. But Mr. Alfred Allhusen was more sanguine, and the boring was continued to a greater depth. The result was that no salt-bed was found, but some very interesting cores of limestone were brought up.

I examined these cores, and on one occasion I was accompanied by Mr. Howse, Curator of the Museum of Natural History, Newcastleon-Tyne, and Dr. Veitch, of Middlesborough. Mr. Howse saw that the limestone was fossiliferous, and his well-trained eye at once detected the small Axinus (Axinus dubius), and it was also noted that a roestone bed similar to one which occurs in the limestone forming the cliffs at Hartlepool had been passed through. Here then I think there is undoubted proof that the red rocks rest upon the uppermost division of the Durham Permian, as at Seaton Carew.

I now wish to direct attention to the western outcrop of the red rocks in the neighbourbood of Darlington, Leeming Lane (where the Vale of Mowbray Brewery is situate), and Ripon. There we have sandstone and marls underlaid by thick deposits of gypsum (as much as 40 feet was proved at the well at the Vale of Mowbray Brewery), which in turn rest directly upon the Permian Limestone. Here, however, they rest, not upon the upper division-the Hartlepool beds-but upon the fossiliferous and compact limestone zone of the Durham Permian - that division which immediately overlies the Marl Slate. It is on these grounds that I think there is some evidence of an unconformity, and that the red rocks may be transgressive over the various divisions of the Durham Permian Limestone from Hartlepool to Darlington and Leeming Lane.

I may add a word upon the lowest set of beds-limestones, and marls with gypsum and rock salt (14 ft.) - proved in the trial borehole of Messrs. Bell Brothers at Saltholme beneath the main bed of rock-salt.

The late Director-General of the Geological Survey, Professor (now Sir Andrew) Ramsay, in his Presidential Address to the British Association at the meeting at Swansea in 1880 , refers to this lowest set of beds, and claims the 14 feet bed of rock-salt proved beneath the limestone to be of Permian age. He says, "In the North of England, at and near Middlesborough, two deep boreholes were made some years ago in the hope of reaching the Coalmeasures of the Durham Coal-field. One of them at Saltholme was sunk to a depth of 1355 feet. First they passed through 
74 feet of superficial clay and gravel, next through about 1175 feet of Red Sandstones and Marls with beds of rock-salt and gypsum. The whole of these strata (excepting the clay and gravel) evidently belong to the Keuper Marls and Sandstones of the upper part of our New Red series. Beneath these they passed through 67 feet of dolomitic limestone, which in this neighbourhood forms the upper part of the Permian series, and beneath the limestone the strata consist of 27 feet of gypsum and rock-salt and marls, one of the beds of rock-salt having a thickness of 14 feet. This bed of Permian Salt is of some importance, since I have been convinced for long that the British Permian strata were deposited, not in the sea, but in salt lakes comparable in some respects to the Great Salt Lake of Utah, and in its restricted fauna to the far greater salt lake of the Caspian Sea."

I do not think the late Director-General ever saw the cores of the strata passed through in the Saltholme boring, but I examined them, and I think he must have formed his opinion from the recorded section and ny description of them, and also from analyses of two samples of the limestones, one taken from the bed at the depth of $126 \mathrm{l}$ feet, and the other at a depth of 1320 feet. These analyses were kindly given to me by Mr. T. Hugh Bell for the use of the Geological Survey, and I showed them to the late Director-General who visited me in his official capacity when I was resident in Darlington.

Mr. Edward Wilson is not inclined to admit the Permian age of these "limestones" and the salt-bed which has been proved beneath them. He demurs to the use of the term "limestone" as applied to the whole of these beds, and designates them instead "indurated marls." $\mathrm{He}$ adds, "Although there appear to be dolomitic or calcareous, as well as dark bituminous beds among them, they show no sort of resemblance to any known berls of the Magnesian Limestone of Durham; on the other hand, they possess the characteristic greenish colour of certain Keuper Marls, as well as a similar texture, and probably also mineral composition, although decidedly harder than most of the rock of that series." On these grounds Mr. Wilson classes these strata with the Keuper division of the Trias.

I append the analyses, of what I believe to be fair samples of the strata bored throngh at the depths above mentioned, and they seem to me to be something more than "indurated marls."

Sample of Magnesian Limestone from the bore-hole (Saltholme), 1261 feet:-

\begin{tabular}{|c|c|c|c|c|c|c|c|c|}
\hline \multicolumn{3}{|c|}{ Carbonate of lime } & $\cdots$ & & & $\cdots$ & $\cdots$ & $54 \cdot 71$ \\
\hline$"$ & & tesia & $\ldots$ & $\cdots$ & $\cdots$ & $\ldots$ & $\ldots$ & $41 \cdot 18$ \\
\hline & & $\ldots$ & ... & $\ldots$ & $\ldots$ & $\ldots$ & $\ldots$ & $\cdot 81$ \\
\hline Silica & .. & $\ldots$ & $\ldots$ & $\ldots$ & $\cdots$ & $\ldots$ & $\ldots$ & $2 \cdot 00$ \\
\hline Alumina & .. & $\ldots$ & $\ldots$ & $\ldots$ & $\ldots$ & $\ldots$ & $\ldots$ & trace \\
\hline Water & .. & $\ldots$ & $\ldots$ & $\ldots$ & $\ldots$ & $\ldots$ & $\ldots$ & 1.08 \\
\hline Bitumen & .. & $\ldots$ & ... & $\ldots$ & $\cdots$ & ... & $\ldots$ & $\cdot 22$ \\
\hline
\end{tabular}


Limestone from the bore-hole, underlying the Magnesian Limestone, "sample $1320 \mathrm{ft}$. depth :-

$$
\begin{aligned}
& \begin{array}{llllllll}
\text { Carbonate of lime } & \ldots & \ldots & \ldots & \ldots & \ldots & \ldots & 94 \cdot 48
\end{array} \\
& \begin{array}{ccccccccr}
, ", " & \multicolumn{2}{c}{\text { magnesia }} & \ldots & \ldots & \ldots & \ldots & \ldots & 2 \cdot 98 \\
\text { Silica } ", & \text { iron } & \ldots & \ldots & \ldots & \ldots & \ldots & \ldots & \cdot 78 \\
\text { Alumina } & \ldots & \ldots & \ldots & \ldots & \ldots & \ldots & \ldots & 1 \cdot 20 \\
\text { Bituminous matter } & \ldots & \ldots & \ldots & \ldots & \ldots & \ldots & \ldots & 0 \cdot 20 \\
& & & & & \ldots & \ldots & \ldots & \cdot 36 \\
\hline
\end{array}
\end{aligned}
$$

Mr. Howse in a paper entitled a "Note on the South I)urham Salt Borings, with remarks on the Fossils found in the MagnesianLimestone Cores, and the Geological Position of the Salt," ${ }^{1}$ of which be has kindly sent me a copy, discusses the age of the limestones and underlying salt-bed and marls at the Saltholme boring. He strongly supports the view that they are of Permian age. He examined the cores soon after the boring was completed, and "came to the conclusion that this limestone and marl were identical with the Upper Limestone and Red Marl of Sedgwick, the Brotherton Beds, and Red Marl of Kirkby, as exposed at Knottingly, Brotherton, and other places in the south of Yorkshire ; and that it was also identical with the 'Plattendolomit' of Geinitz, as seen near Gera, in the outskirts of the Thuringerwald, and many other parts of Germany."

\section{IV.-Coal in the South East of England.}

By W. Whitaker, B.A., F.R.S., F.G.S.

"WTITH regard to the probability of coal under cretaceous rocks in the South of England it seems hardly possible to conceive that the commercial enterprise of Englishmen could have failed to discover it long ago if it had been in existence."

The above quotation, from a Presidential Address, by Mr. H. Hall, ${ }^{2}$ might serve as the text for a short discourse on the commercially unenterprising character of one's fellow-countrymen, who have done practically nothing in the matter!

A deep trial-boring was certainly made some years ago, near Battle: but the Sub-Wealden Boring was not a matter of commercial enterprise. Other deep borings have also been made in the South of England, which partake more of the character of work referred to, though only as regards the getting of water, not the least idea of looking for coal having influenced those who made them. It is indeed to the enterprise of corporations, of companies, and of Government, in the search for water, that we owe almost all our direct knowledge of the rocks underlying the Cretaceous beds of the London Basin.

Just one trial-boring is being made in search for coal, strange to say by a Railway Company; but, though extraordinary rumours

1 Natural History Transactions of Northumberland, Durham, and Neweastle-onTyne, vol. $x$, part ii.

2 Trans. Manchester Geol. Soc. vol. xx. p. 388, and earlier in various weekly newspapers. 